DOI: 10.35757/RPN.2010.18.06

Piotr Madajczyk

\title{
WPŁYW 1968 ROKU NA KSZTAŁTOWANIE OBRAZU POLSKI I POLAKÓW W NIEMIECKIEJ OPINII PUBLICZNEJ
}

Wydarzenia roku 1968 mają już bogatą literaturę przedmiotu, przydatną jednak tylko $\mathrm{w}$ ograniczonym zakresie $\mathrm{w}$ analizie interesującego nas tematu. $\mathrm{W}$ badaniach prowadzonych $\mathrm{w}$ Polsce koncentrowano się przede wszystkim na wydarzeniach Marca 1968 roku, osadzonych w uwarunkowaniach autorytarnego państwa. Pierwszym z historyków badających naukowo te wydarzenia był Jerzy Eisler, który po latach powrócił do nich, przygotowując całościowe opracowanie o "polskim roku 1968", w którym konsekwentnie nadal skupił się na wydarzeniach w Polsce ${ }^{1}$. Praca ta pozostaje najlepszym opracowaniem, mimo że ukazały się inne, liczne publikacje. Podstawowy punkt odniesienia stanowi w nim analiza kryzysu systemu społeczno-politycznego, co zasadniczo poszerza perspektywę postrzegania ówczesnych wydarzeń.

Zachowała swoją wartość analiza kampanii antysyjonistycznej pióra Dariusza Stoli ${ }^{2}$. Zarówno o samym Marcu, jak i o nim w szerszym kontekście politycznym Polski powojennej pisał Andrzej Friszke ${ }^{3}$,

1 J. Eisler: Marzec 1968. Geneza, przebieg, konsekwencje, Warszawa 1991; idem: Polski rok 1968, Warszawa 2006.

2 D. Stola: Kampania antysyjonistyczna w Polsce 1967-1968, Warszawa 2000.

3 A. Friszke: Nad geneza Marca 1968. Konflikt w PZPR na Uniwersytecie Warszawskim 1965-1967, w: Polskie przemiany. Uwarunkowania i spory. Refleksje z okazji jubileuszu profesora Tadeusza Kowalika, Warszawa 2002; idem: Oaza na Kopernika. Klub Inteligencji Katolickiej 1956-1989, Warszawa 1997; idem: Opozycja polityczna w PRL 1945-1980, Londyn 1994; idem: Ruch protestu w marcu 1968 (w świetle raportów MSW dla kierownictwa PZPR), „Więź" 1994, nr 3. 
a także Jakub Karpiński i Krystyna Kersten. Michała Głowińskiego i Piotra Osękę interesowały problemy propagandy i używanego w niej języka ${ }^{4}$. Ogromnie ważne poznawczo są analizy przebiegu wydarzeń 1968 roku w poszczególnych regionach Polski ${ }^{5}$. Pojawiła się pierwsza, niedoskonała jeszcze, ale ważna i wartościowa biografia Mieczysława Moczara $^{6}$, umożliwiająca lepsze zrozumienie kontekstu wewnątrzpolitycznego. Dwukrotnie ukazały się prace zbiorowe, stanowiące podsumowanie badań o Marcu: w końcu lat dziewięćdziesiątych i w roku $2004^{7}$. Cenną inicjatywą jest wydawane przez Instytut Pamięci Narodowej wydawnictwo źródłowe Marzec 1968 w dokumentach MSW. Stanowi ono pierwszy tak szeroko zakrojony projekt, przygotowany na podstawie informacji, meldunków, sprawozdań i notatek milicyjnych i departamentów MSW. Wprawdzie pojawiło się wcześniej kilka publikacji źródłowych, ale miały one wyrywkowy charakter ${ }^{8}$. Autorzy wszystkich tych prac koncentrują się na aspektach wewnątrzpolitycznych.

W polskich badaniach i w polskiej pamięci historycznej Marzec '68 stanowi przeważnie odrębną całość, w niewielkim stopniu jest postrzegany jako fragment szerokiej fali protestu, która przetoczyła się w końcu lat sześćdziesiątych nie tylko przez państwa zachodnie, ale i kraje Ameryki Południowej. Często spotykana jest ocena, że możliwe jest co najwyżej porównanie sytuacji w Polsce i Czechosłowacji. W niewielkim zakresie dostrzega się problemy recepcji i wpływu wydarzeń w innych

4 M. Głowiński: Nowomowa po polsku, Warszawa 1990; idem: Marcowe gadanie. Komentarze do słów 1966-1971, Warszawa 1991; idem: Propaganda marcowa z perspektywy ćwierćwiecza, „Przegląd Historyczny” 1993, nr 3; P. Osęka: Syjoniści, inspiratorzy, wichrzyciele. Obraz wroga w propagandzie marca 1968, Warszawa 1990. Osęka wydał ponadto w wersji popularnonaukowej Marzec '68, Warszawa 2008.

5 W. Suleja: Dolnośląski Marzec '68, Warszawa 2006; J. Kwiek: Marzec 1968 w Krakowie w dokumentach, Kraków 2008; P. Madajczyk: Opolskie środowisko akademickie na tle sytuacji regionu w 1968 r. (w świetle sprawozdań miejscowych Stużby Bezpieczeństwa), "Studia Śląskie” 2004, t. 63; Specjalny numer „Dziejów Najnowszych” (2008, nr 1) poświęcony rokowi 1968.

6 K. Lesiakowski: Mieczysław Moczar "Mietek”. Biografia polityczna, Warszawa 1999.

7 M. Kula, P. Osęka i P. Zaremba (red.): Marzec 1968. Trzydzieści lat później, t. 1, Warszawa 2001; K. Rokicki i S. Stępień (red.): Oblicza Marca 1968, Warszawa 2004.

8 F. Dąbrowski, P. Gontarczyk i P. Tomasik (red.): Marzec 1968 w dokumentach MSW, t. 1: Niepokorni, Warszawa 2008, t. 2: Kronika wydarzeń, Warszawa 2009. Tam też omówienie wcześniejszych publikacji źródłowych. 
państwach na społeczeństwo polskie, ale i recepcji roku 1968 w Polsce przez opinię publiczną innych krajów.

Wzajemne oddziaływanie wydarzeń w poszczególnych krajach istotniejsze jest w pracach, w których podejmowane są próby szerszego nakreślenia przemian roku 1968, tak aby ująć je w skali ponadnarodowej. Ponadnarodowy charakter miały przecież, przykładowo, odbywające się w 1968 roku igrzyska olimpijskie: letnie w Meksyku i zimowe w Grenoble. Wydarzenia sportowe uwikłane były w dokonujące się przemiany społeczno-polityczne, zarówno w proces emancypacji czarnoskórych obywateli USA (protest Tommie Smitha i Johna Carlosa w Meksyku), jak i ruchy studenckie (kontakty Harry Edwardsa z meksykańskimi studentami w ruchu na rzecz bojkotu igrzysk) ${ }^{9}$. Wcześniej powstały całościowe ujęcia, obejmujące - mniej lub bardziej wyczerpująco - państwa zachodnie. Za taką udaną próbę uważana jest książka Arthura Marwicka, w której zajął się on przede wszystkim historią kultury, a pominął aspekty polityczne ${ }^{10}$. Mimo poszerzania perspektywy brakuje nadal całościowego, globalnego spojrzenia na ówczesne wydarzenia. Państwa byłego bloku wschodniego włączył do swych rozważań Norbert Frei, rozpatrując wydarzenia $\mathrm{w}$ Polsce przede wszystkim w politycznym kontekście, ale także wskazując na niewielki zakres zmian stylu życia polskich studentów ${ }^{11}$. Ingrid Gilcher-Holtey rozpoczęła swe badania od Maja '68 w Paryżu, poszerzyła następnie ujęcie na kraje zachodnie (RFN, Francja, Włochy, USA). Jej postulatem było uhistorycznienie badań, krytyczne zweryfikowanie interpretacji ówczesnych wydarzeń, traktowanych jako ruch społeczny (soziale Bewegung) ${ }^{12}$.

Dyskusja o roku 1968 uległa w Polsce silnemu upolitycznieniu, czego zapewne nie można było całkowicie uniknąć, szczególnie że podobny proces dostrzegalny jest także w innych krajach. Ocena wpływu ówczesnych wydarzeń na przemiany społeczne i polityczne wiąże się przecież

9 Zob. Amy Bass: Not the Triumph but the Struggle: The 1968 Olympics and the Making of the Black Athlete, Minneapolis 2007.

${ }^{10}$ A. Marwick: The Sixties: Social and Cultural Transformation in Britain, France, Italy and the United States, New York 1998.

${ }^{11}$ N. Frei: 1968. Jugendrevolte und globaler Protest, München 2008.

${ }^{12}$ I. Gilcher-Holtey (red.): 1968 - vom Ereignis zum Gegenstand der Geschichtswissenschaft, Göttingen 1998; D. della Porta: „1968“ - Zwischennationale Diffusion und Transnationale Strukturen, w: Gilcher-Holtey (red.): op. cit., s. 131-150. 
silnie z poglądami politycznymi, z ocena, które z tych przemian miały konsekwencje pozytywne, a które - negatywne. Daleko idące upolitycznienie dyskusji o roku 1968 widoczne było w Niemczech, gdy sprawa Joschki Fischera wyniosła ją na pierwsze strony gazet. Upolityczniona jest pamięć we Francji: skoncentrowana na Maju, a marginalizująca szerszy kontekst ruchów społecznych, idealizująca ówczesne wydarzenia i spychająca w niepamięć eksplozje przemocy, zapominająca o istotnym udziale ruchu robotników-imigrantów ${ }^{13}$. W nowszych opracowaniach zwraca się uwagę na konieczność przełamania opisu opartego na autoprezentacji uczestników wydarzeń '68 - autoprezentacji stanowiącej kontynuację zaangażowania $\mathrm{w}$ nich i płynącej $\mathrm{z}$ tego dumy. Norbert Frei ma rację przestawiając „rok '68” jako skomplikowaną przestrzeń skojarzeń, powstałą w wyniku społecznego dyskursu, opartą zarówno na interpretacjach wydarzeń, jak i wyobraźni. Przestrzeń, w której historykowi łatwo się zagubić ${ }^{14}$.

Polski kierunek upolitycznienia dobrze pokazuje wydanie przez wydawnictwo „Fronda” wspomnień córki Ulrike Meinhof, Bettiny Röhl, eksponującej zależność zachodnich lewicowych aktywistów roku '68 od wschodniego (Berlin Wschodni i Moskwa) wsparcia i pieniędzy ${ }^{15}$. Jest to niewątpliwie aspekt ciekawy, a przy tym chętnie pomijany milczeniem przez osoby zaangażowane $\mathrm{w}$ roku '68, ale nieumożliwiający zrozumienia skali i znaczenia zapoczątkowanych wówczas przemian społecznych, kulturowych i politycznych. Z drugiej strony wydane zostało $\mathrm{w}$ Polsce tłumaczenie bardzo ciekawej pracy Paula Bermana, w której, wychodząc od sprawy J. Fischera, próbuje on określić dalsze losy i rozwój ideowy niektórych członków "pokolenia '68". Nie tych, którzy destrukcyjnie zatracili się $\mathrm{w}$ radykalizmie swoich haseł, ale tych, którzy poszli drogą prowadzącą do akceptacji demokracji i odrzucenia wszelkich form totalitaryzmu ${ }^{16}$.

${ }^{13}$ M. Zancarini-Fournel: Vom Mai 68 zu den "68er Jahre”, w: Gilcher-Holtey (red.): op. cit., s. 101-115.

${ }^{14}$ Por. Frei: op. cit., s. 210-211: „Das ist kein Frondienst im Steinbruch der Geschichte, sonder Narzissmus als selbstbestimmte Arbeit am Mythos, das hält offensichtlich jung und die Erinnerung vermeintlich frisch".

${ }^{15}$ B. Röhl: Zabawa w komunizm. Ulrike Meinhof, Klaus Reiner Röhl i prawdziwe korzenie nowej lewicy (1958-1968), Warszawa 2007. Wydanie książki uzyskało wsparcie w ramach jednego z programów finansowanych przez Ministra Kultury i Dziedzictwa Narodowego.

${ }^{16}$ P. Berman: Władza i idealiści, Warszawa 2008. 
Frei podkreślał, że tzw. rok ' 68 nie był żadnym rokiem, ale pewną epoka, że to, co nazywa się rokiem ' 68 , zaczęło się w USA na początku lat sześćdziesiątych, $\mathrm{w}$ wielu innych krajach $\mathrm{w}$ połowie tych lat, a jedynie we Francji ograniczone było do roku $1968^{17}$. W Polsce w tym samym kierunku poszedł Jerzy Eisler, uznając w przytaczanej na początku książce Polski rok 1968, że ówczesne wydarzenia zrozumieć można jedynie w kontekście politycznych i społecznych przemian lat sześćdziesiątych. Rok ' 68 był jedynie punktem kulminacyjnym znacznie bardziej długotrwałych i złożonych procesów.

Przed paru laty Marcin Kula, zastanawiając się nad studentami jako grupą szczególnie skłonną do buntu, doszedł do wniosków, jak samokrytycznie stwierdził, o dość ograniczonej przydatności poznawczej:

„W jakim stopniu wnioski wyciągnięte $\mathrm{z}$ refleksji nad krajami Trzeciego Świata tłumaczą inne ruchy studenckie? Prawdę mówiąc, w niewielkim - poza ogólnikami w rodzaju stwierdzenia, iż za młodu jest się podpalaczem, podczas gdy na starość strażakiem. W krajach rozwiniętych, gdzie miały miejsce wielkie ruchy studenckie, trudno mówić o braku strukturalizacji społeczeństwa i braku ukształtowania się innych grup społecznych - co pozostawiałoby miejsce dla substytucyjnej siły studenckiej. Trudno też mówić o braku ekspresji innych grup społecznych.

W ruchach studenckich krajów rozwiniętych wielką rolę odgrywał kierunek kontrkultury. Tymczasem w krajach biednych niszczenie samochodów i zrywanie asfaltu z ulicy w celu pokazania, że pod spodem jest naturalny piasek, wywołałoby pytanie o stan psychiki demonstrantów.

Wnioski nasuwające się z obserwacji doświadczenia Trzeciego Świata znacznie lepiej odnoszą się natomiast do świata komunistycznego. Ten przypominał Trzeci Świat zarówno w wymiarze zacofania gospodarczego i prób jego przełamania, jak w niejednej kwestii politycznej. Tu także studenci bardziej myśleli o polityce niż o niszczeniu samochodów, które - przeciwnie - chcieli posiadać. Tu także rodziły się rozliczne frustracje na tle dysonansu pomiędzy pożądanym, a faktycznym stanem rozwoju kraju. Tu także studenci mieli szanse być najbardziej świadomą rzeczywistości oraz może najbardziej ekspresyjną grupą - bowiem innym pozostawał jedynie bunt podejmowany w ostateczności. Tu także,

\footnotetext{
${ }^{17}$ Frei: op. cit., s. 212-213.
} 
jak w Trzecim Świecie, bunt studencki krystalizował się o tyle łatwiej, że rodził się na pograniczu elity, wręcz na pograniczu establishmentu (podobnie jak bunt szerzej rozumianej inteligencji)"18 ${ }^{\prime 1}$.

Jeżeli jednak postrzegamy rok '68 jako epokę, to różnice wskazane powyżej nie są tak istotne. Protest koncentrował się w krajach autorytarnych na problemie wolności, a najsilniej widoczne było to w Polsce. W krajach Trzeciego Świata dominowały problemy społeczne i ekonomiczne. W krajach zachodnich panowała wspaniała epoka wzrostu gospodarczego i dobrobytu po strasznym doświadczeniu wojny, a zarazem nieumiejętność poradzenia sobie z nowymi aspiracjami młodzieży, odwołującymi się do wolności, poszerzenia demokracji, partycypacji w niej i jej przejrzystości.

Ciekawą płaszczyznę stanowi przynależność do tej samej generacji, bo przecież wielu polskich studentów utożsamiało się z międzynarodowym ruchem protestu. Chciało bardziej wolnego, nieskrępowanego stylu życia, więcej demokracji, wierzyło w „nową” lewicę, aczkolwiek w rozumieniu tych pojęć różniąc się często (dorastając w państwach posttotalitarnych) istotnie od swoich zachodnich kolegów (dorastających w, niedoskonałych wprawdzie, demokracjach ${ }^{19}$. Nie jest przy tym istotny fakt, wskazany przez Freia, że skala zmiany stylu życia polskich studentów nie była zbyt wielka. Istotne jest podobne jak wśród młodzieży krajów zachodnich pragnienie tych zmian i przekonanie, że są one możliwe.

Podział generacyjny znajdował ponadto w Polsce specyficzne odbicie. W krajach zachodnich oznaczał przede wszystkim bunt przeciwko starszemu pokoleniu jako narzucającemu tradycyjne i nieaktualne normy i wartości. W Polsce w takich kategoriach interpretować można tracenie przez starzejącą się ekipę Gomułki poparcia wśród ludzi młodych.

${ }^{18}$ M. Kula: Studenci jako grupa rewoltogenna, w: Rokicki i Stępień (red.): op. cit., s. 224-229. Cytat s. 228.

${ }_{19}$ Por. B.J. Falk: The Dilemmas of Dissidence in East-Central Europe. Citizen Intellectuals and Philosopher Kings, Budapest-New York 2003, s. 26. Zbyt odmienne były uwarunkowania, czyniąc polską młodzież (ale i w innych krajach bloku) bardziej odporną na naiwną wiarę $\mathrm{w}$ odnowicielską siłę komunizmu chińskiego, kubańskiego lub wietnamskiego. Zachodni studenci z czerwonymi kolorami, portretami Mao i hasłami demokracji rad wydawali się wielu polskim kolegom naiwni, por. M. Dülffer: 1968 - Eine europäische Bewegung?, http://www.eurotopics.net/de/archiv/magazin/geschichte-verteilerseite-neu/achtundsechzig-2008-03/debatte-1968-2008-03/. 
Ponadto widoczne było generacyjne pęknięcie, gdy ruch '68 roku nie zyskał poparcia starszych robotników, mających odmienne doświadczenia życiowe. Nie był jednak skierowany przeciwko nim i czuł się kontynuatorem polskiej tradycji narodowej.

W polskiej perspektywie brakuje postawienia ważnego badawczo pytania, jak wydarzenia 1968 roku wpłynęły na obraz Polski, polskiego społeczeństwa, polskiej historii w światowych mediach i międzynarodowej opinii publicznej. Które z polskich wydarzeń 1968 roku miało wpływ silniejszy: demokratyczny protest przeciw dyktaturze czy antysemicka kampania, która wywarła negatywne wrażenie? Ta ostatnia nakładała się na wcześniejsze dyskusje o historii Żydów w Polsce i oskarżenia o współodpowiedzialność Polaków za holocaust, czyli kampania antysemicka 1968 roku w Polsce nałożyła się na trwające już polemiki. W 1967 roku ukazała się pod redakcję Zofii Lewinówny i Władysława Bartoszewskiego książka Ten jest z ojczyzny mojej. Polacy z pomoca Żydom 1939-1945 (Kraków 1966). W takiej atmosferze Kazimierz Iranek-Osmecki zdecydował się na przygotowanie, także jako polemiki, książki Kto ratuje jedno życie... . W tym czasie ukazywały się już publikacje Tadeusza Walichnowskiego, w których autor piętnował współdziałanie Izraela i zachodnioniemieckich rewizjonistów ${ }^{20}$.

Celem niniejszego artykułu jest ukazanie różnych interpretacji wydarzeń 1968 roku w Polsce. Ponieważ nie jest to ujęcie całościowe, nie jest w nim istotne określenie rangi i zasięgu oddziaływania poszczególnych publikacji, czy to naukowych, czy też popularnych.

\section{Konflikt polsko-czechosłowacki}

Chwila, w której doszło do wydarzeń 1968 roku, była dla Polski bardzo niekorzystna, gdyż jej autorytet na międzynarodowej scenie słabł.

${ }^{20}$ K. Iranek-Osmecki: Kto ratuje jedno życie... Polacy $i \dot{Z} y d z i$ 1939-1945, Warszawa 2009. Por. Wstęp, s. 52. W książce sprawy antysemityzmu poruszane były w sposób powściągliwy, aczkolwiek nie przemilczane. Silnie podkreślone zostały oskarżenia wobec państw zachodnich i działających w nich organizacji żydowskich o bezczynność wobec holocaustu. Por. też K.-P. Friedrich: Der nationalsozialistische Judenmord in polnischen Augen: Einstellungen der polnischen Presse 1942-1946/47, Internet Fassung, Überarbeitete Fassung der Dissertation, Universität zu Köln, Köln 2002, s. 69-105. 
Procesy demokratyzacji zostały zahamowane, władze odwoływały się coraz silniej do instrumentów przemocy oraz mobilizowania społecznego poparcia za pomocą nacjonalistycznej ideologii. Odpowiednio do potrzeb politycznej sytuacji wewnętrznej manipulowano w polskich mediach przekazem o wydarzeniach w innych krajach.

Pierwszym obszarem, w którym polityka komunistycznych władz w Warszawie kolidowała z wartościami zachodnich społeczeństw, było jej współdziałanie w tłumieniu procesu demokratyzacji w Czechosłowacji. Praska Wiosna wywołała ogromny rezonans w świecie zachodnim, podobnie jak i jej siłowe stłumienie.

Do 1968 roku wydawało się, że będzie możliwe utrzymanie przemian w Czechosłowacji $\mathrm{w}$ ramach określanych przez polityczny system państw bloku wschodniego. Ambasada polska w Pradze oceniła, podsumowując rok 1967, że zmiany dokonywane są w sposób odpowiedzialny i zdyscyplinowany. Tym samym, pisano, można przypuszczać, „że rozwój ogólny zmierza, w sposób kontrolowany, w kierunku stabilizacji”21. Także Gomułka otrzymywał od Aleksandra Dubczeka, szczególnie podczas rozmowy w Ostrawie 7 lutego 1968 roku, zapewnienia o panowaniu nad sytuacją $\mathrm{w}$ kraju ${ }^{22}$. W tym czasie złożył wizytę w Czechosłowacji Stefan Jędrychowski, podczas której rozmawiał, komplementując go, z prezydentem Ludvikiem Svoboda, a potem z Dubczekiem: w celu „doprowadzenia do pełnej normalizacji stosunków z naszymi krajami i przyjęcia odpowiedniego planu działania w tym zakresie". Stronie polskiej chodziło o ponowne nawiązanie kontaktów partyjnych między przygranicznymi województwami oraz na szczeblu centralnym. Dubczek zapewniał swego rozmówcę o chęci zacieśniania współpracy między partiami i przekazaniu już odpowiednich propozycji „partiom 5-ki”. Podkreślał brak różnic między PZPR i Komunistyczną Partią Czechosłowacji (KPCz) w kluczowych sprawach socjalizmu, polityki międzynarodowej, Układu Warszawskiego i Rady Wzajemnej Pomocy

${ }^{21}$ Notatka, zapewne Włodzimierza Janurka (skreślone i na jednym egzemplarzu dopisane A. Małecki), dotycząca wstępnej oceny sytuacji w CSRS po grudniowo-styczniowym Plenum KC Komunistycznej Partii Czechosłowacji (KPCz), 17 stycznia 1968, Archiwum Ministerstwa Spraw Zagranicznych (dalej AMSZ), sygn. 9/74, D.ICz0-242-1-68.

${ }^{22}$ Rozmowa w: A. Garlicki i A. Paczkowski: Zaciskanie pętli. Tajne dokumenty dotyczace Czechostowacji 1968 r., Warszawa 1995, s. 15-48. 
Gospodarczej (RWPG). Natomiast Jędrychowski mówił o podważaniu kierowniczej roli partii komunistycznej, pogłoskach o powrocie do dawnych miejsc zamieszkania wysiedlonych Niemców sudeckich, szeroko lansowanym haśle neutralności Czechosłowacji. Dubczek dystansował się od tych sformułowań jako „nieodpowiedzialnych poglądów”. Przypomniał za to, jako aktualne, czechosłowackie projekty kooperacji z Polską w przemyśle oraz deklarował poparcie dla RWPG i planów wzmocnienia integracji gospodarczej ${ }^{23}$.

Władze polskie wyraźnie obawiały się w tym czasie wpływu czechosłowackich przemian na społeczeństwo polskie, uważnie obserwowały osoby kontaktujące się z południowym sąsiadem, inwigilowały osoby studiujące tam, bardzo dokładnie sprawdzano korespondencję i kontrolowano pas przygraniczny. W marcu słychać było podczas demonstracji studenckich okrzyki na cześć Czechosłowacji i dokonujących się tam przemian. Odwoływano się do nich w ulotkach ${ }^{24}$.

Podczas narady I sekretarzy partii komunistycznych z Polski, Węgier, Bułgarii, NRD i CSRS w Dreźnie 23 marca 1968 widoczne było krytyczne wobec sytuacji w Czechosłowacji stanowisko Gomułki. Narada ta była ponadto zwołana w dużym stopniu z jego inicjatywy. Przyznać trzeba, że na podstawie własnych doświadczeń 1956 roku, Węgier 1956 roku oraz Marca 1968 roku Gomułka prawidłowo ocenił niestabilność władzy KPCz i nierealność jej utrzymania w przypadku zniesienia represyjnych mechanizmów kontroli. Przyłączył się do opinii Leonida Breżniewa o wydarzeniach w Pradze jako kontrrewolucji. Sam także ocenił ją podobnie, aczkolwiek jako dokonującą się na pokojowej drodze metodę rozkładu systemu od wewnątrz. Dostrzegł jak niebezpieczne dla autorytarnego systemu jest wprowadzenie kilku konkurencyjnych list wyborczych ${ }^{25}$.

Niezadowolenie władz w Warszawie budziło krytyczne nastawienie w Czechosłowacji wobec wydarzeń Marca. Protesty przekazywały

${ }^{23}$ Notatka S. Jędrychowskiego z rozmów z Prezydentem CSRS L. Svoboda, I Sekretarzem KC KPCz A. Dubczekiem i premierem CSRS - O. Czernikiem, luty 1960, AMSZ 1/77.

${ }^{24}$ Ujęcie tej problematyki, jak też podsumowanie dotychczasowych badań $\mathrm{w}$ tym zakresie: M. Białokur: Z perspektywy czterdziestolecia. Historiografia polska wobec przełomowych wydarzeń 1968 roku w Polsce i w Czechosłowacji, w: D. Kisielewicz i M. Świder (red.): Marzec '68 z czterdziestoletniej perspektywy, Opole 2009, s. 47-66.

${ }^{25}$ Por. Garlicki i Paczkowski: op. cit., s. 7-8. 15-48, 61-77; List KPZR z 4 lipca i PZPR z 5 lipca 1968 do KPCz w: AAN, KC PZPR 1740, s. 11-24. 
różne środowiska, przede wszystkim studenckie, ale także osoby prywatne, krytykując interwencję milicji przeciw studentom, wyrażając solidarność z nimi i oburzenie z powodu kampanii antysemickiej. Jako organizacja wystąpił jedynie Związek Pisarzy Czechosłowackich. Warszawski MSZ poświęcał protestom wiele uwagi, przygotowując zestawienia cytatów, chociaż nie wydaje się, żeby starał się przesadnie eksponować ich skalę ${ }^{26}$. Przy tym władze czechosłowackie przekazywały już w marcu sygnały, że ukazujące się w mediach komentarze nie odzwierciedlają ich stanowiska, które nie uległo zmianie.

W PZPR dominowało przekonanie, że w Czechosłowacji narastają antypolskie (mogło to oznaczać zarówno wrogie wobec Polski, jak i wrogie wobec systemu komunistycznego w Polsce) nastroje, a władze w Pradze nie przeciwdziałają temu. 16 marca ambasador PRL w Pradze interweniował w tej sprawie w Wydziale Międzynarodowym KC KPCz i u wiceministra spraw zagranicznych. 29 marca Józef Winiewicz przekazał zastrzeżenia czechosłowackiemu ambasadorowi w Warszawie. 2 kwietnia ambasador PRL w Pradze przekazał ustny protest czechosłowackiemu wiceministrowi spraw zagranicznych Josephowi Pudlakowi. 20 kwietnia zastępca kierownika Wydziału Zagranicznego KC PZPR, Marian Renke, zwracał uwagę ambasadorowi czechosłowackiemu na "fałszywe informacje” w prasie. Kontynuując tę małą wojnę dyplomatyczna, ambasador PRL 22 kwietnia rozmawiał z Przewodniczącym Rządu CSRS, U. Czernikiem. Wiceminister Kruczkowski rozmawiał ponownie 3 maja z czechosłowackim ambasadorem o „antypolskiej kampanii". Zwieńczenie tych działań stanowiła przekazana 6 maja polska nota do czechosłowackich władz ${ }^{27}$.

${ }^{26}$ Por. notatkę Departamentu I MSZ z 28 marca 1968, sygn. 9/74, w. 3, DICz.0-24-368 , s. $17-20$.

${ }^{27}$ Nota KC PZPR i nota rządu PRL do KC KPCz i rządu CSRS z 6 maja 1968, Archiwum Akt Nowych, KC PZPR 1739, s. 349-352. Pisano w niej: „Od wielu tygodni w prasie, także w organach partyjnych, radio i telewizji czechosłowackiej systematycznie pojawiają się tendencyjne, wypaczone, złośliwe i wręcz wrogie informacje oraz komentarze o Polsce. Ta antypolska kampania nasila się niepokojąco z każdym dniem, a jej formy stają się coraz bardziej napastliwe”. O opublikowanym 4 maja w „Prace” liście trzech pisarzy, Pavla Kohouta, Jaroslava Prochazki, Arnošta Lustiga, stwierdzano: „Zawiera pozbawione podstaw przedstawienie wydarzeń w Polsce i ich niezgodną z rzeczywistością ocenę: imputuje nam prowadzenie polityki antysemickiej, bierze w obronę antysocjalistyczne i antypaństwowe elementy w Polsce". Przypominano demonstrację przed 
Odpowiedź Pragi przekazana została polskiemu ambasadorowi 23 maja. Padały w niej na wstępie zapewnienia o przyjaźni z ZSRR i innymi krajami bloku jako podstawie czechosłowackiej polityki oraz o kontynuowaniu tej polityki w przyszłości. Odwoływano się do układu polsko-czechosłowackiego, a akcentowane w polskiej nocie artykuły oceniane były jako nieistotne w skali ogólnej ${ }^{28}$. W atmosferze narastającej niechęci do Pragi Józef Winiewicz pisał o megalomańskich nastrojach tam panujących, przekonaniu o szczególnym znaczeniu CSRS w procesie demokratyzacji, uważaniu tego, co czeskie, za najlepsze. Krytycznie oceniał słabnący krytycyzm wobec Zachodu oraz słabnięcie propagandy na rzecz informacji: „Informacja o Bliskim Wschodzie uległa całkowitemu zobiektywizowaniu". Za błąd uważał powściągliwą krytykę RFN w czechosłowackich mediach oraz przecenianie znaczenia sił liberalnych w zachodnich Niemczech. Nie ma, twierdził, w czechosłowackich mediach istotniejszych informacji o krajach bloku ${ }^{29}$.

Oceny te współgrały z przekonaniem, że CSRS łamie ustalenia odnośnie do prowadzenia wspólnej polityki wobec RFN, nie konsultuje swoich działań z innymi krajami bloku, ukrywa rozbudowywanie kontaktów ${ }^{30}$. Zmiana polityki Pragi postrzegana była przez Gomułkę i MSZ jako wynik skutecznego wpływu zachodnioniemieckiej polityki różnicowania bloku wschodniego, niosąca niebezpieczeństwo „rewizji uzgodnionego wspólnego stanowiska wobec NRF" oraz końca planów reformy RWPG i stworzenia „żelaznego trójkąta”. Gomułka był zwolennikiem zdecydowanych działań, doprowadzenia do polaryzacji sił w Czechosłowacji, aby ostatecznie zlikwidować wpływ przeciwników systemu.

ambasadą PRL w dniu 1 maja i podczas wiecu 3 maja. Krytykowano sztukę „Wniebowstąpienie Saszki Krista” jako pełną „inwektyw pod adresem Polaków”. Twierdzono, że 23 kwietnia w praskiej TV wyemitowano wywiad z A. Lustigiem, który porównał kierownictwo PZPR do hitlerowców i zarzucił władzom polskim dyskryminowanie Żydów, prześladowanie ich, pozbawianie pracy i wyrzucanie z Polski.

${ }^{28}$ Tekst listu KPCz i Rządu CSRS, tłumaczenie z języka czeskiego, AMSZ 1/77. Też korespondencja w sygn. 9/74, w. 3, D.ICz-0-22-/3/68.

${ }^{29}$ Notatka Winiewicza z 20 kwietnia 1968 Sytuacja w Czechosłowacji, AMSZ 1/77. Przeznaczona była dla najwyższych członków władz.

${ }^{30}$ Por. wystąpienie Gomułki w lipcu 1968 roku w: Garlicki i Paczkowski: op. cit., s. 128-129. Breżniew mówił podczas narady w lipcu w Warszawie zasadniczo o sprawach ideologicznych, Gomułka najpierw o dezintegracji bloku i zmianie polityki wobec RFN, a dopiero potem o ideologii. 
Zdecydowanie odrzucał krytykę interwencji ze strony Jugosławii, uważając ją za szczególnie szkodliwą. Przeciwny był ustępstwom wobec postulatów partii komunistycznych z krajów zachodnich, gdyż podlegały one $\mathrm{w}$ jego ocenie coraz silniejszym wpływom rewizjonistycznym, przekształcając się w socjaldemokratyczne. Zajmował stanowisko wyraźnie odmiennie od Breżniewa, który akcentował znaczenie jedności ruchu komunistycznego. Gomułka w nią już nie wierzył, stawiał na państwa i partie mające stanowić twarde jądro systemu komunistycznego ${ }^{31}$.

Jak widać z powyższego opisu, społeczeństwo polskie nie miało realnego wpływu na decyzje podejmowane przez władze partyjno-państwowe, ale udział wojsk polskich w interwencji w Czechosłowacji nie był wymuszony na Warszawie przez Moskwę. Wprost przeciwnie, Gomułka uważał go za konieczny i zgodny z polskimi interesami, naciskał na podjęcie decyzji o interwencji, podobnie jak Walter Ulbricht i Todor Żiwkow. Zdołał także wywrzeć istotny wpływ na społeczeństwo polskie propagandowym obrazem czechosłowackich przemian, jako dokonywanych pod zachodnioniemieckim wpływem, grożących okrążeniem Polski przez Niemcy od południa, przez wyrwanie Czechosłowacji z Układu Warszawskiego. Wobec silnych antyniemieckich nastrojów i obaw w Polsce prowadziło to do zaakceptowania przez dużą część społeczeństwa interwencji wojskowej jako nieuniknionej.

Oddziaływanie decyzji o interwencji i polskim w niej udziale na postrzeganie Polski przez międzynarodową opinię publiczną mogło być tym silniejsze, że Praska Wiosna stała się symbolem wolnościowych dążeń w skali znacznie przekraczającej jej faktycznie nie tak wielkie polityczne znaczenie. Znajduje to odbicie $w$ większości opracowań, gdyż $\mathrm{w}$ tych poświęconych opozycji w bloku wschodnim więcej miejsca poświęca się Polsce, a w tych poświęconych latom sześćdziesiątym - Czechosłowacji. Mimo to podjęta przez Gomułkę decyzja o udziale polskich wojsk w stłumieniu Praskiej Wiosny nie jest obecnie zasadniczo postrzegana jako obciążająca polskie społeczeństwo, ale jako uwarunkowana doktryną Breżniewa ${ }^{32}$.

\footnotetext{
${ }^{31}$ Por. wypowiedzi podczas narady 27 września w Moskwie w: Garlicki i Paczkowski: op. cit., s. 208-245.

${ }^{32}$ Por. takie ujęcie M.J. Ouimet: The Rise and Fall of the Brezhnev Doctrine in Soviet Foreign Policy, Chapel Hill, NC 2003. Też w związanej z lewicową Fundacją im. Róży
} 


\section{Wpływ kampanii antysemickiej na obraz Polski}

Trudniejszym problemem pozostaje wyważenie w opisie roku 1968 w Polsce proporcji między znaczeniem ruchu na rzecz demokratyzacji systemu a polityczną siłą antysemickiej polityki ówczesnych władz w Warszawie i społecznym poparciem dla niej. Czy antysemicka kampania była jedynie narzędziem manipulacji władz, przy pomocy którego niszczono ruch na rzecz demokratyzacji, czy też odwoływała się do silnych nastrojów antysemickich, a to oznacza: antydemokratycznych, w społeczeństwie polskim. Tak sformułowane pytania powoduja, że dyskusja o 1968 roku staje się także częścią kontrowersji wokół antysemityzmu w Polsce po 1945 roku.

W 1968 roku reakcja w Niemczech na antysemicką kampanię władz w Warszawie była o tyle słabsza, że niemiecką opinię publiczną znacznie bardziej interesowały wydarzenia w Pradze niż w Warszawie, a i w polsko-niemieckim obszarze zajmowały ją inne problemy. Przede wszystkim analizowano stosunek Polski do zapoczątkowanej przez SPD „polityki wschodniej”. W marcu media informowały o demonstracjach studentów oraz antyżydowskiej propagandzie władz polskich, mówiących o spisku żydowsko-zachodnioniemieckim. Informacje z Polski stały się rzadsze od maja, a komentatorzy zajmowali się w nich przede wszystkim rozgrywkami o władzę wewnątrz PZPR. Wkrótce nastąpiła interwencja państw Układu Warszawskiego w Czechosłowacji, całkowicie przesłaniając sprawy polskie ${ }^{33}$.

Negatywny wpływ kampanii antysemickiej na obraz Polski na Zachodzie nie budzi wątpliwości, jakkolwiek nie należy go przeceniać. W niemieckiej wersji Wikipedii, do której najczęściej sięga przeciętny

Luxemburg publikacji pokonferencyjnej: A. Ebbinghaus (red.): Die letzte Chance? 1968 in Osteuropa. Analysen und Berichte über ein Schlüsseljahr, Hamburg 2008. Analogiczna forma opisu w: H. Carrère d'Encausse: Big Brother: The Soviet Union and Soviet Europe, New York 1987. W pracy J. Rothschilda: Return to Diversity: A Political History of East Central Europe since World War II, New York 2000, na temat Gomułki pada stwierdzenie, o "his willing role in snuffing out the Prague Spring despite the contrary sentiments of the Polish people" (s. 194).

${ }^{33}$ Por. M. Świder: Wydarzenia 1968 roku w Polsce i w Czechosłowacji w środkach masowego przekazu Republiki Federalnej Niemiec, w: Kisielewicz i Świder (red.): op. cit., s. 225-239, tutaj s. 225. 
użytkownik Internetu, opis zaczyna się od stwierdzenia, że: „Wydarzenia marcowe w Polsce w 1968 roku to określenie politycznego kryzysu, który rozpoczął się wraz demonstracjami studentów, m.in. w Warszawie, Gdańsku i Krakowie. Zamieszki zostały stłumione przez jednostki milicji i ochotników spośród wojskowych rezerwistów, tzw. aktywistów robotniczych". W opisie rozróżnione zostały jasno dwa obszary: protestów społecznych na rzecz udemokratycznienia systemu oraz antysemickiej polityki władz jako narzędzia prowadzenia polityki wewnętrznej i zwalczania protestó $w^{34}$. Podobnie w wersji angielskiej wyeksponowany został protest przeciw dyktaturze: „ważny protest studentów i intelektualistów przeciwko komunistycznym władzom PRL, represje wobec nich aparatu bezpieczeństwa i równoczesna kampania »antysyjonistyczna «, rozpoczęta przez polski rząd w reakcji na polityczny kryzys. [...] Fala antysemityzmu, podsycanego przez władze PRL jako część »antysyjonistycznej« kampanii służyła taktycznie odwróceniu publicznej uwagi od politycznego kryzysu w kraju i doprowadziła ostatecznie do masowej ucieczki Żydów z Polski" ${ }^{35}$.

Także w części opracowań historycznych nie widać wpływu antysemickiej kampanii w Polsce w 1968 roku na kształtowanie się jej negatywnych stereotypów. Dotyczyć to może zarówno prac o charakterze encyklopedycznym ${ }^{36}$, jak i ogólnohistorycznym ${ }^{37}$. Zgodnie $z$ opisanym

${ }^{34}$ Pada jednak stwierdzenie: „Die Geschehnisse zusammen mit den antisemitischen Kundgebungen verdunkelten das Bild Polens in westlichen Ländern“, März-Unruhen 1968 in Polen, http://de.wikipedia.org/wiki/M\%C3\%A4rz-Unruhen_1968_in_Polen.

${ }^{35} 1968$ Polish political crisis, http://en.wikipedia.org/wiki/1968_Polish_political_crisis. Zasadniczo w analogicznej tonacji utrzymane jest hasło w języku rosyjskim.

${ }^{36}$ W Europe Since 1945: An Encyclopedia, New York 2001, znajdujemy krótki, ale rzeczowy opis pod hasłem Poland: „Despite criticism by the Catholic Church, the authorities imprisoned students, dissolved six faculties of Warsaw University, and fired some professors, among them the philosopher Leszek Kolakowski, and forced about 30,000 people of Jewish origin to immigrate. Gomułka stayed in power thanks to the backing of Edward Gierek, a leader of the economic administrators, adopting anti-Jewish slogans and retaining the support of the USSR". W wydanej w latach osiemdziesiątych niemieckiej serii „Das zwanzigste Jahrhundert. Europa nad dem Zweiten Weltkrieg”, Frankfurt am Main 1983, mowa jest jedynie o ruchu Moczara i wykorzystaniu przezeń kampanii antysyjonistycznej (s. 429-430).

37 Przykładowo D.S. Mason w Revolution and Transition in East-Central Europe, Boulder 1996, nie zajmuje się antysemityzmem, a jedynie stwierdza: „The 1968 demonstrations were met with harsh reprisals and purges of students and professors, especially those of Jewish origin" (s. 26). Podobna perspektywa: Frei: op. cit., s. 197-202. 
na początku wzorem postrzegania ówczesnych wydarzeń, opisywane są jako dwa odrębne problemy: (1) manipulowanie przez komunistów antysemityzmem, aby w kryzysowej sytuacji skanalizować niezadowolenie społeczne i utrzymać ster władzy oraz (2) stłumiony siłą demokratyczny protest ${ }^{38}$. Skuteczność manipulacji była jednak możliwa, ponieważ władze odwołały się do realnie istniejących nastrojów społecznych, wrogości wobec Żydów i obcych ${ }^{39}$. Wskazuje się także wewnątrzpolskie korzenie kampanii antysemickiej, która nie była inspirowana z Moskwy ${ }^{40}$.

Niektórzy autorzy eksponują użycie przez komunistyczne władze polskie nastrojów antysemickich jako narzędzia w polityce wewnętrznej, koncentrując się na polityce komunistycznych władz jako głównym czynniku sprawczym ówczesnych wydarzeń ${ }^{41}$. Pokazywane jest manipulowanie przez władze mitem żydowskiego zagrożenia oraz jego znaczenie dla ideologii narodowego komunizmu ${ }^{42}$. W tej perspek-

${ }^{38}$ Por. R. Frucht (red.): Encyclopedia of Eastern Europe: From the Congress of Vienna to the Fall of Communism, New York 2000, s. 610.

${ }^{39}$ "After the student revolts over half of all Jewish people at this time still resident in Poland were in fact forced to emigrate. [...] Through this anti-Semitic strategy the party leadership succeed in isolating the student movement, since the large parts of society this campaign had fallen on fertile ground", S. Sonntag: Poland, w: D. Pollack i J. Wielgohs (red.): Dissent and Opposition in Communist Eastern Europe. Origins of Civil Society and Democratic Transition, Wiltshire 2004, s. 7. Autorka odwoływała się przy tym wniosku do ustaleń M. Zaremby i D. Stoli. Podobnie B.J. Falk: The Dilemmas: „The campaign was successful, especially given the ability of the authorities to play on long-standing antipathies of average workers and citizens - both Jews and activist were effectively silenced and »othered «" (s. 24). Za przyczynę społecznej podatności na manipulację uważa antysemityzm, ksenofobiczny nacjonalizm i religijny mesjanizm. Następnie analizuje jednak ogromną rolę roku '68 dla kształtowania się opozycji w Polsce.

${ }^{40}$ M. Dülffer: 1968-Eine europäische Bewegung? (http://www.eurotopics.net/de/archiv/magazin/geschichte-verteilerseite-neu/achtundsechzig-2008-03/debatte-1968-2008$-03 /)$.

${ }^{41}$ M.B. Biskupski: The History of Poland, Westport 2000, s. 131; R.J. Crampton: Eastern Europe in the Twentieth Century and After, London 1997, s. 318-319.

${ }^{42}$ Por. opis polityki władz partyjno-państwowych: J.N. Michlic: Poland's Threatening Other: The Image of the Jew from 1880 to the Present, Lincoln, NE 2006, aczkolwiek odwołujących się do postaw antysemickich: „The ethno-nationalist Communist elites also used the myth as a rationale and justification for firing Jewish employees from scientific and cultural institutions, publishing houses, and national radio and television stations. [...] This people were replaced by ethnic Poles, who were either faithful followers of the PZPR's propaganda, opportunists, or both" (s. 256). Za bardziej przekonującą uznaje argumentację Marcina Zaremby o podatności istotnej części społeczeństwa na hasła antysemickie niż Jerzego Eislera - o traktowaniu ich z dystansem. Równocześnie pisze o odporności pewnych grup społeczeństwa na propagandę antysemicką. 
tywie dostrzegane są zachowania odmienne od oficjalnej linii władz, np. związanej z Kościołem katolickim redakcji „Tygodnika Powszechnego" ${ }^{43}$.

W innych ujęciach wątek antysemicki był mocniej eksponowany, ulegając ponadto wzmocnieniu przez połączenie z aktualnymi dyskusjami i silne upolitycznienie ${ }^{44}$. Nierzadko nabierał charakteru emocjonalnego, gdyż rok 1968 postrzegany jest nie bez racji jako ostateczny cios w społeczność żydowską w Polsce. W tej perspektywie punkt wyjścia do dyskusji o roku 1968 stanowi wskazanie na problemy antysemityzmu w Polsce po II wojnie światowej. Nierzadko brakuje jednak precyzyjnego określenia, jak wyglądały powiązania między polityczną płaszczyzną wydarzeń a społeczną reakcją na nie ${ }^{45}$. Jak wyglądała realizacja projektu, zgodnie z chętnie przez wielu cytowaną wypowiedzią Adama Michnika, powiązania władzy komunistycznej z tradycją polskiej skrajnej prawicy? Wychodząc od podkreślania związku między wzrostem w latach sześćdziesiątych nacjonalizmu i antysemityzmu ${ }^{46}$, formułowana jest teza, że wydarzenia roku 1968 zostały w latach osiemdziesiątych wyparte w Polsce ze zbiorowej pamięci, aby obciążona Marcem ideolo-

43 „During the anti-Semitic campaign of 1968 Turowicz resolutely continued to publish Jewish writers, and when the Polish-Jewish poet Antoni Słonimski was blacklisted for criticizing official anti-Semitism, Turowicz invited him to join the staff of Tygodnik Powszechny as a contributing editor", S.P. Ramet: Social Currents in Eastern Europe: The Sources and Meaning of the Great Transformation, Durham, NC 1991.

${ }^{44}$ Por. dyskusje o publikacjach J.T. Grossa oraz głośny artykuł K. Sauerlanda we „Frankfurter Allgemeine Zeitung” z 15 lutego 2008. Bardzo mocno podkreślał on w nim konsekwencje emigracji “68 roku: „Nach meinem Empfinden ist die durch den Exodus 1968 entstandene Lücke bis heute nicht geschlossen worden, denn an den Universitäten änderte sich auch nach der Wende wenig. Vor allem befreiten sich die Hochschulen nicht von jenen, die 1968 als »Aktive« hervorgetreten waren. Über ihre Taten beziehungsweise Untaten herrscht Stillschweigen. Heute sind diese Leute zumeist pensioniert oder bereits verstorben, jedoch ihr Geist lebt in vielem und bei vielen weiter". Cytowany artykuł Sauerlanda oraz inne jego publikacje i wystąpienia na konferencjach miały ogromny wpływ na kształtowanie, szczególnie w niemieckich mediach, obrazu '68 roku w Polsce.

${ }^{45}$ Por. Tagungsbericht Internationaler Workshop Poland 1968 „The Jewish Escape and Communism within the People's Republic", 5 maja 2008-6 maja 2008, Leipzig, w: H-Soz-u-Kult, 18 grudnia 2008 (<http://hsozkult.geschichte.hu-berlin.de/tagungsberichte/id=2449>).

${ }^{46}$ Por. też K. Sauerland: Polen und Juden zwischen 1939 und 1968, Jedwabne und die Folgen, Berlin-Wien 2004. 
gia narodowa, dzięki zapomnieniu o jej powiązaniu z akcją antysemicką, mogła stać się przeciwwagą dla komunizmu ${ }^{47}$.

Według części historyków rok 1968 ma kluczowe znaczenie jako doświadczenie studenckiego protestu przeciw organizowaniu przez władze antyinteligenckiej i antysemickiej nagonki, ale - co najważniejsze - symbolizuje samoorganizowania się społeczeństwa. Co zrozumiałe, w tym kontekście szczególna rola przypada Adamowi Michnikowi ${ }^{48}$. Jako szczególnie ważny i pozytywny fakt podkreślane jest to, że po 1968 roku nastąpiło w Polsce wypracowanie modelu obywatelskiej, antypolitycznej (anti-politics) opozycji. Doświadczenie Marca przyniosło zrozumienie, że zmiana polityczna, zarówno ze względu na uwarunkowania polskie, jak i sowieckie, nie jest możliwa. Dlatego należało się zaangażować w obszarze społecznym, który nie tylko był jedynym możliwym do działania, ale i znacznie ważniejszym. Ważniejsze bowiem od zmian politycznych było zbudowanie aktywnego, świadomego, silnego społeczeństwa ${ }^{49}$.

47 "Second, the effusive public memorialization of 1970 in the 1980 strikes masks the nearly complete omission of the student rebellions in 1968 which sparked a major anti-semitic movement from the pantheon of sacrificial events. 1968 has become a nonevent, even though several important individuals of the intellectual wing of Solidarity began their activism there. One important effect of this omission is to preserve nationalism for the liberal opposition, to construct nationalism as anti-communism in reference to the 1980 strikes, by eliminating the memory of Communist-backed nationalist invectives against Jews. (Of course, in the years since 1980, nationalism has become a complex issue in Poland, and in the post-Communist period the Grunwald-inspired racial/religious nationalism is alive and well, especially in the political activities of the Catholic church)", K.S. Long: We All Fought for Freedom: Women in Poland's Solidarity Movement, Boulder, CO 1996, s. 40.

48 "My personal experience is the experience of a man...who was imprisoned for the first time twenty-five years ago in March 1965, who participated in the 1968 student uprising in protest against the anti-intellectual and anti-Semitic hue-and-cry organized by the Communist bureaucracy in Poland, who stubbornly wanted to be part of the independent community, and who saw that this community was being systematically disrupted by the force of police crackdowns", A.M. Cirtautas: The Polish Solidarity Movement: Revolution, Democracy and Natural Rights, London 1997, s. 171.

${ }^{49}$ Takie postrzeganie wpływu doświadczenia 1968 w Polsce: D. Ost: Solidarity and the Politics of Anti-politics: Opposition and Reform in Poland since 1968, Philadelphia 1990, s. 2: "The opposition rejected the state not just because it could not win there, but also because it did not want to win there. It was inspired by the same radical views of politics that inspired the new left in the West. This opposition did not want to possess power so much as to abolish it. It was, before all else, anti-authoritarian. KOR and Solidarity were directly connected to this radical opposition of ' 68 through personal and intellectu- 
Jak widać z tego wstępnego zestawienia, recepcja wydarzeń roku 1968 w Polsce przez międzynarodową opinię publiczną, a także historiografię nie była jednolita. Dostrzegano w nich zarówno elementy pozytywne - ruch społeczny na rzecz demokracji, jak i negatywne - poza polityką komunistycznych władz także antysemityzm i nacjonalizm. W opracowaniach historycznych wydaje się dominować odwołanie do elementów pozytywnych. Sytuacja w mediach wymaga jeszcze dokładniejszej analizy, gdyż silniej biorą w nich górę emocje.

\section{Abstract \\ The impact of 1968 on the shaping of the image of Poland and the Poles in German public opinion}

The article is an initial presentation of the problem of the reception of the Polish events of 1968 in other countries, and in particular, in Germany. Two areas have been subjected to a preliminary scrutiny. The first pertains to the attitude to Czechoslovakia and the participation of the Polish armed forces in suppressing the Prague Spring by force. This participation is interpreted as a result of the Brezhnev Doctrine. What is more controversial is the balancing of the relations between the positive elements, namely, a pro-democracy social movement, and the negative ones which, apart from the policy of the Communist authorities, also included anti-Semitism and nationalism as social phenomena. References to the positive elements seem to dominate in historical studies. The situation in the mass media requires an even more detailed analysis, as emotions take the upper hand there.

al linkages alike. So ",anti-politics" is not just the necessary rejection of the state but also the deliberate rejection of the state, the belief that what is essential to a just order is not a benign government and good people in power, but rather a vital, active, aware, self-governing, and creative society. The opposition turned to civil society not just because there was no other public sphere in which it could immerse itself, but also because there was no other in which it wanted to immerse itself". 